\title{
Research on the Influence of the Mode of Home with Joint Property Rights on the Commercial House Prices Based on Synthetic Control Methods_-Taking Huangshi City as An Example
}

\author{
Fengjuan Liu',a, Yao Zhao ${ }^{2, b}$ \\ ${ }^{1}$ Wuxi Environmental Science and Engineering Research Center, Wuxi, China \\ ${ }^{2}$ Wuxi Environmental Science and Engineering Research Center, Wuxi, China
}

\begin{abstract}
By the synthetic control method and monthly panel data of 21 cities from March 2008 to December 2014, this paper analyzes the effects of the mode of housing with common property rights and regulation policy on commodity housing prices of Huangshi City and the sensitivity of housing prices to policies. The results show that the effect of the mode of home with joint property rights on the commodity house price of Huangshi City is not significant, which shows that the commodity house price of Huangshi City is less sensitive to the related regulatory policies. Therefore, this paper suggests that the government should establish new special housing management institutions or adjust, improve the responsibilities of the existing housing management institutions, expand the number of applicants for home with common property rights, especially for those who have the prominent contributions to the society, which can be allowed to apply the housing with the joint property rights even if they are in the middle income level, restructure or standardize the existing management system, laws and regulations and set up an effective management system for participating in the construction and management of home with common property rights.
\end{abstract}

\section{Introduction}

In recent years, the house price has been rising in China. Accordingly, as shown in Table 1, Chinese Government has successively promulgated the relevant policies to curb the trend of soaring of the house price because the level of the price of the housing directly affects the people's life. After all, the house is the most basic living demand of the people for Chinese.

In Table 1, on October 15, 2009, Huangshi City was officially approved by the Ministry of Housing and Urban Rural Development as the national pilot city for the construction of public rental housing system ${ }^{[1]}$. In August 2010, the Interim Measures for the Administration of Public Rental Housing in Huangshi City was promulgated. On November 15, 2010, the New Century reported that the affordable housing would be uniformly reallocated by Huangshi municipal government and come into home with joint property rights of Huangshi City. In March 2011, all kinds of indemnificatory housing of Huangshi would be converted into public rental housing, which will be allocated by the government in a unified way" [2]. However, The shantytown reconstruction started in late
December 2009. But in the beginning, the mode is only in the exploration process, and only for the public rental housing. Therefore, the paper select October, 2010 as the time of the split point of the synthetic control to analyze the impact of the mode of home with joint property rights on house prices from October 2010 after considering various factors.

TABLE 1 THE BEGINNING OF MODEL OF HOME WITH JOINT PROPERTY RIGHTS IN PILOT AREAS AND SUBSEQUENT MACRO-CONTROL POLICIES

\begin{tabular}{|l|l|l|}
\hline $\begin{array}{l}\text { The } \\
\text { serial } \\
\text { number }\end{array}$ & $\begin{array}{l}\text { The time of the } \\
\text { implementation } \\
\text { of policies }\end{array}$ & Related policies \\
\hline 1 & 2007.8 & $\begin{array}{l}\text { Huai'an, Jiangsu } \\
\text { Province first } \\
\text { established the mode of } \\
\text { the mutual-property } \\
\text { right housing }\end{array}$ \\
\hline 2 & 2009.10 & $\begin{array}{l}\text { Huangshi City was } \\
\text { approved as the } \\
\text { national pilot city for } \\
\text { the public-renting } \\
\text { houses system }\end{array}$ \\
\hline 3 & 2010.8 & Interim Measures for \\
\hline
\end{tabular}




\begin{tabular}{|c|c|c|}
\hline & & $\begin{array}{l}\text { the management of the } \\
\text { public rental housing in } \\
\text { Huangshi City }\end{array}$ \\
\hline 4 & 2011.3 & $\begin{array}{l}\text { All kinds of } \\
\text { indemnificatory } \\
\text { housing in Huangshi } \\
\text { will be converted into } \\
\text { public rental housing, } \\
\text { which will be allocated } \\
\text { by the government in a } \\
\text { unified way }\end{array}$ \\
\hline 5 & 2011 & $\begin{array}{l}\text { Shanghai defined the } \\
\text { concept of shared } \\
\text { ownership house }\end{array}$ \\
\hline 6 & 2012.2 & $\begin{array}{l}\text { China's central bank } \\
\text { cut the reserve } \\
\text { requirement ratio }\end{array}$ \\
\hline 7 & 2013.2 & $\begin{array}{l}\text { The State Council } \\
\text { promulgated the five } \\
\text { regulations of China's } \\
\text { property market to curb } \\
\text { the real estate market } \\
\text { and firmly speculative } \\
\text { and investment-driven } \\
\text { housing demand }\end{array}$ \\
\hline 8 & 2013.3 & $\begin{array}{l}\text { the rules for the } \\
\text { implementation of the } \\
\text { five regulations: raise } \\
\text { down payments and } \\
\text { mortgage rates on } \\
\text { second-home sales and } \\
\text { levy } 20 \% \text { tax on selling } \\
\text { houses }\end{array}$ \\
\hline 9 & 2014.2 & $\begin{array}{l}\text { The "two sessions" put } \\
\text { forward "classified } \\
\text { regulation" to give } \\
\text { local governments } \\
\text { more autonomy }\end{array}$ \\
\hline 10 & 2014.5 & $\begin{array}{l}\text { The People's Bank of } \\
\text { China has taken some } \\
\text { mini-stimulation } \\
\text { measures such as "the } \\
\text { five regulations of the } \\
\text { central bank" and } \\
\text { making targeted cuts } \\
\text { to required reserve } \\
\text { ratios to guarantee the } \\
\text { credit demand of home } \\
\text { purchase }\end{array}$ \\
\hline 11 & 2014.6 & $\begin{array}{l}\text { Six cities, including } \\
\text { Beijing, Shanghai, } \\
\text { Shenzhen, Chengdu, } \\
\text { Huangshi and Huai'an, } \\
\text { are definitely listed as } \\
\text { the pilot cities with } \\
\text { home with joint } \\
\text { property rights }\end{array}$ \\
\hline
\end{tabular}

Many scholars and institutions have done a lot of research on the public housing for middle and lowincome groups, and many countries have a lot of practical experiences such as the shared ownership or the shared equity housing in the United Kingdom ${ }^{[3,4,5]}$, the public housing in the United States ${ }^{[6,7,8]}$, apartment blocks in Singapore ${ }^{[9]}$, affordable housing or collaborative housing in Sweden and Denmark ${ }^{[10]}$, public housing in Hong Kong $\left.{ }^{[1]}\right]$ and government-built apartment complex in Japan,. Among them, the housing security system of most countries are designed for improving the living conditions of low and middleincome residents or controlling the rapid rising price, etc. In addition. some scholars think housing cooperatives $^{[12,13,14]}$ have played an important role in some countries.

Furthermore, the synthetic control method selected in this paper is more suitable for the areas that have implemented certain policy, while other areas have not implemented it. In this way, data of other areas can be used to synthesize the data of the target area so as to reflect the impact of the implementation of the policy on the region. In other words, the method can reflect the impact of the policy on the local city from the perspective of counterfactual. For example, Abadie et al. (2003) used the synthetic control method to study the economic cost of conflicts in Basque area for the first time ${ }^{[15]}$; Abadie (2010) also applied the synthetic control method to analyze the impact of California's Proposition 99 about the tobacco control program on the tobacco consumption in California, and used the data of other states to simulate the potential tobacco consumption level of California without implementing the Proposition [16]. What's more, Abadie (2014) also estimated the economic impact of the reunification of Germany on West Germany in 1990 with the synthetic control $\operatorname{method}^{[17]}$.

All in all, up to now, most research literature focuses on the advantages of the mode of the housing with common property rights, the role and function of the government, the scale of possession, case study, and the applicable groups. And the shortcoming is that they seldom consider the impact of this model on the city's housing prices. The synthetic control method used in this paper can make the public find out the impact of the mode of home with joint property rights on the local commercial house prices. And consequently, the result can also further improve the relevant policies.

\section{The influence of the model of home with common property rights on the commercial house price of Huangshi City based on the synthetic control method}

\subsection{Introduction of Synthetic Control Method}

The main idea of the synthetic control method is that the characteristic of the control group gotten from the aggregation of the weights of the existing alternative control units is very similar to that of the experimental group. And accordingly, the control group can be better 
used as the cross reference of the experimental group to further carry out counterfactual analysis.

In this paper, it is assumed that the sample data of $\mathrm{j}+1$ cities at phase $\mathrm{T}$ can be gotten. Among them, number 1 represents Huangshi City, the experimental group city that carries out the mode of home with common property rights, and the other $\mathrm{J}$ cities don't carry out this model. T0 represents the time that the pilot city implements the model (in this paper, it refers to the time before October 2010), $P$ represents the commercial house price. Let $\mathrm{P}_{i t}^{N}$ be the commercial house price of city $\mathrm{i}$ that does not adopt the model at time $t$; Let $\mathrm{P}_{i t}^{I}$ be used to indicate the commercial house price of city $i$ that adopts the model at time t. Therefore, let the formula $\alpha_{i t}=\mathrm{P}_{i t}^{I}-\mathrm{P}_{i t}^{N}$ to represent the impact of the implementation of the model of the housing with mutual property rights on the commercial house price of city i. Let the formula $\alpha_{1 t}=\mathrm{P}_{1 t}^{I}-\mathrm{P}_{1 t}^{N}$ to represent the impact of the implementation of the model on the commercial house prices of Huangshi City. In practice, the commercial house price of one city like Huangshi City with implementing the model can be observed, but the commercial house price of one city without implementing the model cannot be observed. Therefore, the factor model proposed by Abadie et al. (2010) is adopted to make estimation for the price. As shown in equation (1),

$\mathrm{P}_{i t}^{N}=\delta_{t}+\theta_{t} z_{i}+\lambda_{t} u_{i}+\varepsilon_{i t}$

where $\delta_{t}$ represents an unknown common factor with the time fixed effect that affects the price of the commercial housing in all selected cities, ${ }^{z_{i}}$ represents a vetor of the observable covariates that are not affected by the implementation of the mode of housing with common property rights, $\theta_{t}$ represents a vector of unknown parameters, $\lambda_{t}$ represents a vector of unobservable common factors, the symbol ${ }^{\mu_{i}}$ represents fixed effect of the unobservable city, and the error terms

$\varepsilon_{i t}$ represents the unobservable short-term shocks and its mean value equals 0 . For this paper, it is necessary for analyzing the impact of the mode of home with common property right on urban housing prices to estimate the housing prices of Huangshi City that did not implement the mode before. Now, considering the synthetic virtual contrast group synthesized by a $(J \times 1)$ vectors of weights $\left.W=\left(\mathrm{w}_{2}, \cdots, \mathrm{w}_{j+1}\right)\right)^{\prime}$ that consists of $\mathrm{J}$ cities without the model of common property right housing. Among them, $w_{j} \geq 0$ and $w_{2}+\cdots+w_{J+1}=1$. According to the variable values of each control group city, after weighting, the equation (2) is gotten after weighting the variable values of each contrast group city, and shown in the following:

$$
\sum_{j=2}^{J+1} w_{j} \mathrm{P}_{j t}=\delta_{t}+\theta_{t} \sum_{j=2}^{J+1} w_{j} z_{j}+\lambda_{t} \sum_{j=2}^{J+2} w_{j} \mu_{j}+\sum_{j=2}^{J+1} w_{j} \varepsilon_{j t}
$$

Suppose that the weight vector $W^{*}=\left(\mathrm{w}_{2}^{*}, \mathrm{~L}, \mathrm{w}_{j+1}^{*}\right)$ exists, the formulae in the following will be gotten:

$$
\sum_{j=2}^{J+1} w_{j}^{*} \mathrm{P}_{j 1}=\mathrm{P}_{11}, \sum_{j=2}^{J+1} w_{j}^{*} \mathrm{P}_{j 2}=\mathrm{P}_{12}
$$

$$
\sum_{j=2}^{\ldots+1} w_{j}^{*} \mathrm{P}_{j T_{0}}=\mathrm{P}_{1 T_{0}} \quad \sum_{j=2}^{J+1} w_{j}^{*} \mathrm{z}_{j}=\mathrm{z}_{1}
$$

If the expression $\sum_{t=1}^{T_{0}} \lambda_{t}^{\prime} \lambda_{t}$ is non-singular, then the equation (3) will be established.

$$
\begin{aligned}
& \mathrm{P}_{1 t}^{N}-\sum_{j=2}^{J+1} w_{j}^{*} \mathrm{P}_{j t} \\
& =\sum_{j=2}^{J+1} w_{j}^{*} \sum_{s=1}^{T_{0}} \lambda_{t}\left(\sum_{n=1}^{T_{0}} \lambda_{n}^{\prime} \lambda_{n}\right)^{-1} \lambda_{s}^{\prime}\left(\varepsilon_{j s}-\varepsilon_{1 s}\right)-\sum_{j=2}^{J+1} w_{j}^{*}\left(\varepsilon_{j t}-\varepsilon_{1 t}\right)
\end{aligned}
$$

Abadie et al. (2010) proved that if the time period before the policy is longer than that of the implementation of the model of home with common property rights, then the mean value on the right side of the equation (3) will approach 0 . Therefore, during the implementation of the policy, the result of the expression $\sum_{j=2}^{J+1} w_{j}^{*} \mathrm{P}_{j t}$ can be used as the unbiased estimate value of $\mathrm{P}_{j t}$ to get the estimated value of the policy effect.

$$
\hat{\alpha}_{1 t}=\mathrm{P}_{1 t}^{I}-\sum_{j=2}^{J+1} w_{j}^{*} \mathrm{P}_{j t}
$$

Therefore, the value $\alpha_{1 t}$ can be calculated by the weight vector $W^{*}$.

\subsection{Determination of Index Data and Model}

Due to the higher house price, some people usually choose to rent. It is necessary for analyzing the housing price to regard the rent as one of the essential factor of affecting the house price. In addition, factors affecting the house price of one region also include per capita GDP, per capita disposable income in cities and towns, medical conditions like the number of doctors per 10000, and the fiscal spending on education like per capita education expenditure. And the time period of the data selected is from March 2008 to December 2014.

\subsection{An analysis of the Current Situation of House Prices of Huangshi City and the Average House Prices of Other 20 Cities}

First of all, the paper analyzes the trend of the commercial house price of Huangshi City and other 20 cities that did not implement the mode of home with common property rights. As shown in Fig. 1, the house prices of Huangshi City are affected by the model of home with joint property rights or the expectation that all public rental housing were uniformly reallocated by the government in March 2011. And it began to fall from January 2011, and maintained an upward trend, and then come to rise from September 2011. Compared with the trend of the commercial house prices of other 20 cities, the house price of Huangshi City is relatively stable. It indicates that the mode of housing with common property rights has played a significant role in the formulation of the commercial house price. However, by 
the end of December 2014, under the influence of various policies issued by the state, the overall trend of housing prices of Huangshi City is similar to that of other 20 cities. It shows that the model of housing with common property rights does not have significant effect for cities like Huangshi City. Next, by means of the synthetic control method, the paper takes Huangshi City as the experimental group and tanks other 20 cities as the control group to analyze whether the model of home with joint property rights has a certain impact on the commercial house price of Huangshi City.

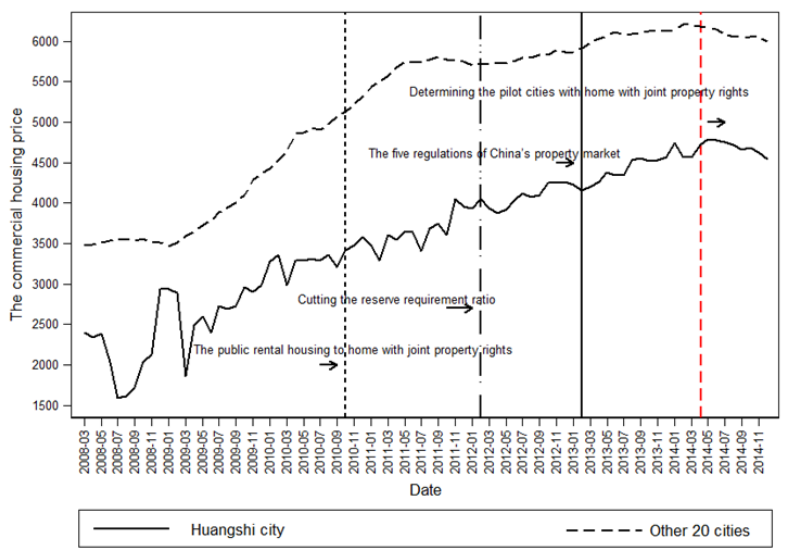

Figure 1 The comparison of the commercial house price of Huangshi City and the average price of the commercial house of synthetic Huangshi City consisting of 20 cities

\subsection{An analysis of the Current Situation of House Prices of Huangshi City and the Average House Prices of Other 20 Cities}

Huangshi city implements the mode of home with common property rights, while the other 20 cities do not. Therefore the house price of the other 20 cities are chosen to synthesize that of Huangshi City, so that we can understand the trend of the house price of Huangshi City without implementing the mode of housing with common property rights to analyze the impact of the model on the commercial house price.

In order to reduce the deviation of short-term effects and resolve the problem of existing data collection, the paper chooses to synthesize those data from March 2008 to December 2014. 70-term data about house prices can reflect the real long-term and short-term impact of various policies like the mode of home with common property rights on the commercial house prices of Huangshi city. The weight of each city that consists of synthetic Huangshi City in the same period is shown in Table 2.

TABLE 2 THE SYNTHETIC HUANGSHI CITIES AND THEIR WEIGHT (2008.3-2014.12)

\begin{tabular}{|l|r|l|r|}
\hline City & $\begin{array}{l}\text { Weight of } \\
\text { The } \\
\text { synthetic } \\
\text { Huangshi } \\
\text { City }\end{array}$ & City & \multicolumn{2}{l|}{$\begin{array}{l}\text { Weight of } \\
\text { The } \\
\text { synthetic } \\
\text { Huangshi } \\
\text { City }\end{array}$} \\
\hline Jincheng & 0.339 & Huzhou & 0 \\
\hline Jiujiang & 0 & Jiaxing & 0.016 \\
\hline Dandong & 0 & Beihai & 0 \\
\hline Handan & 0 & Guiyang & 0.017 \\
\hline Bengbu & 0 & Anyang & 0.269 \\
\hline Anqing & 0 & Harbin & 0.002 \\
\hline Longyan & 0 & Hefei & 0 \\
\hline Kaifeng & 0.025 & Lanzhou & 0 \\
\hline Hengyang & 0 & Nanning & 0 \\
\hline Heyuan & 0.333 & Kunming & 0 \\
\hline
\end{tabular}

Considering the influence of multiple factors such as policies, rent, location, education level, medical environment and per capita GDP on the commercial house prices, the cities of synthetic Huangshi are mainly composed of Jinjiang, Kaifeng, Jiaxing, Guiyang, Anyang and Harbin. Among them, the weight of Harbin is the lowest, Relatively speaking, the weights of Jinjiang, Heyuan and Anyang are relatively higher, which shows that the result after weighting the commercial house prices of these cities reflect the commercial house price of Huangshi City.

In addition, to ensure the validity of synthesis effect, the relatively significant statistical result, and reflect the impact of the implementation of the mode of home with common property rights on the housing price of Huangshi City, the author applied the synthetic control method to make many calculations and verification. The synthetic result is shown in Table 3 and Fig. 2.

TABLE 3 DATA CONTRAST OF HUANGSHI AND SYNTHETIC HUANGSHI (2008.3-2014.12)

\begin{tabular}{|l|r|r|r|}
\hline Index & \multicolumn{1}{|l|}{ Treated } & \multicolumn{1}{l|}{ Synthetic } & $\begin{array}{c}\text { The average of } \\
\text { other 20 cities }\end{array}$ \\
\hline Rent(578(1)608) & 9.551613 & 9.298656 & 12.94284 \\
\hline per capita GDP & 23270 & 20358.01 & 23851.55 \\
\hline Annual per capita disposable income & 13315.5 & 13652.03 & 14942.62 \\
\hline Annual per capita education expenditure & 458.585 & 524.6221 & 481.513 \\
\hline Annual per capita number of doctors & 17.84 & 14.98553 & 18.2245 \\
\hline Commercial house price (February 2009) & 2889 & 2894.871 & 3515.8 \\
\hline
\end{tabular}




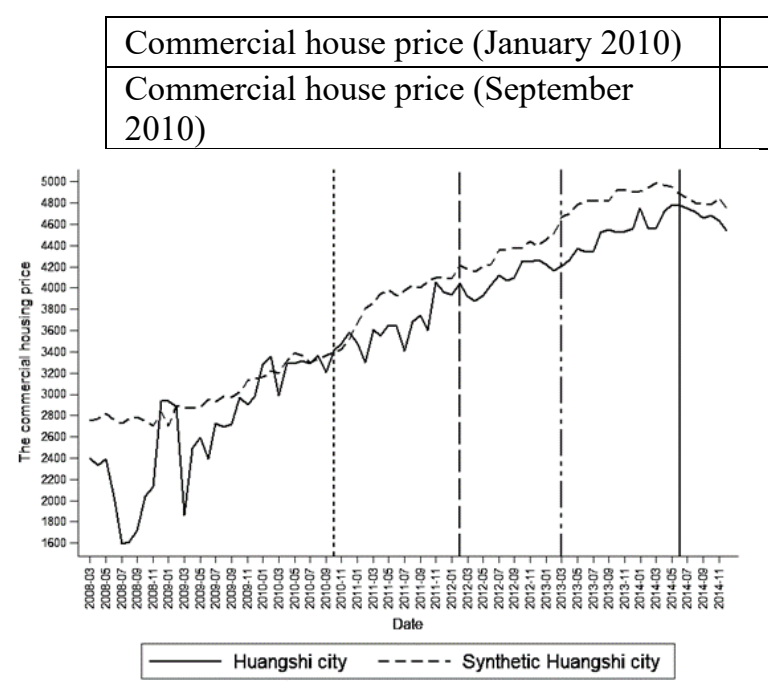

Figure 2 The trend of house price of synthetic Huangshi City without the mode of housing with common property rights by synthetic control method

As can be seen in the Figure 2, the implementation of the mode of housing with common property rights has a small shock on the commercial house prices of Huangshi City from October 2010 to November 2011, while the composite house prices of synthetic Huangshi City without the implementation of the mode in the same period is in the rising stage. It indicates that in this period, the model of home with joint property rights has certain impact on the house price of Huangshi City. And then, the house price has risen rapidly for one month since November 2011. But the fluctuation of the housing price of Huangshi City is similar to that of Huangshi synthesized by 20 cities after the Chinese Government issued to lower the deposit reserve ratio in February 2012 and promulgated the policy about restriction of purchasing housing such as the five regulations of China's property market in February 2013. These data show that the housing prices of Huangshi City have the low sensitivity to these policies. It indirectly indicates that these policies don't have a strong impact on the housing prices of cities like Huangshi City. In June 2014, the trend of the housing price of Huangshi is similar to that of synthetic Huangshi without the implementation of that model after the state determined to set up six pilot cities including Shanghai, Beijing, Huangshi and Huai'an to carry out the mode of housing with common property rights.

\subsection{Robustness Test}

To find out the effectiveness of the result of the synthetic Huangshi, it is necessary for the researcher to verify the significance of the statistical results to determine its robustness. It is well known that in the paper written by Abadie et al. (2010), he puts forward a kind of placebo test method based on the classic randomized reasoning method $^{[15]}$. In principle, supposed that the policy have been implemented in other 20 cities without the mode of housing with common property rights, and then the house price of the city that has implemented the policy

\begin{tabular}{|l|l|l|}
\hline 3281 & 3162.935 & 4422.7 \\
\hline 3208 & 3366.962 & 5077.9 \\
\hline
\end{tabular}

one by one will be synthesized by the house prices of other 20 cities that have not implemented the mode in the contrast group by means of the synthetic method. As a consequence, the gap between the commercial housing price of the city and the synthetic city is gotten, and then all the statistical results are listed out. Next, after compared the difference between the result and the gap between the house price of Huangshi City gotten from the empirical results and the house price of the synthetic Huangshi City, if it is found that the line representing most cities are above that of Huangshi City, it shows that the research result is statistically significant. That is to say, it is reliable for the result that the mode of home with joint property rights have the small impact on the house price of Huangshi City.

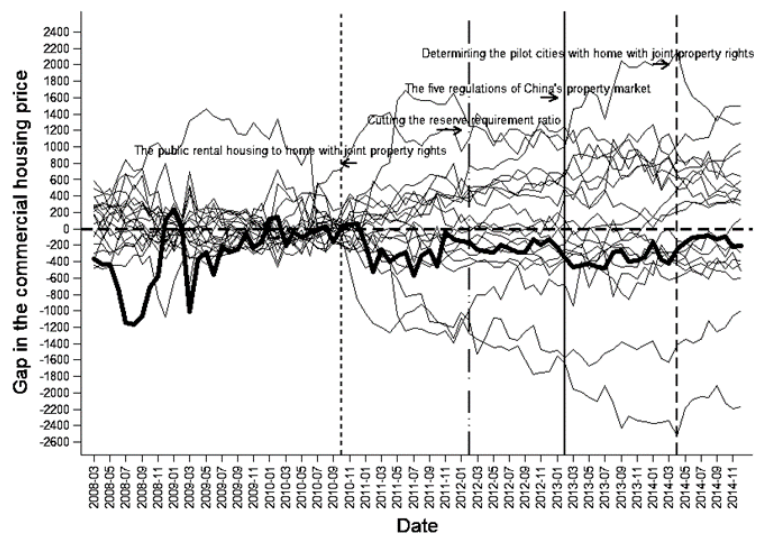

Figure 3 The placebo test method (2008.3-2014.12)

As shown in Fig. 3, the lines representing 20 cities are mostly above the lines representing Huangshi City from October 2010 to November 2011. Namely, the black solid lines representing Huangshi City are basically at the bottom, and basically the three major cities are below Huangshi. Therefore, the results are statistically significant at $15 \%$.

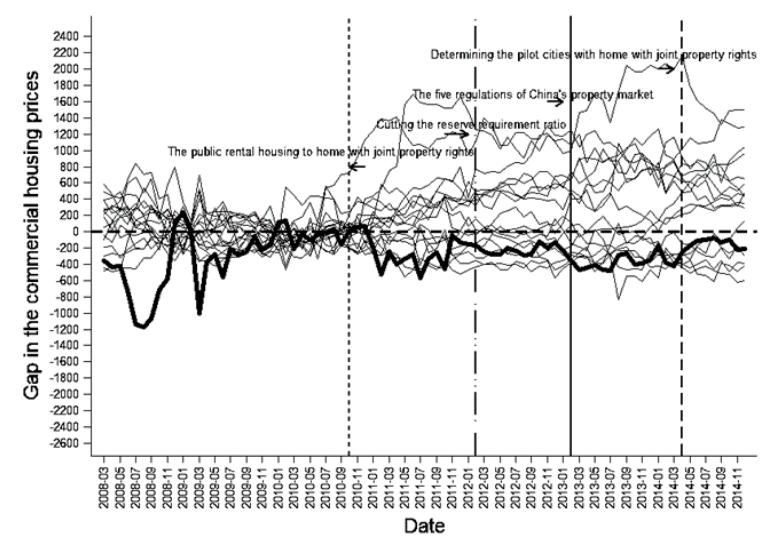

Figure 4. The result of placebo test which remove the one with too high mean square error of prediction

Next, the result as shown in Fig. 4 is gotten after removing the one with too high mean square error of 
prediction in turn. Most of the lines that represent synthetic cities were above the line that represents Huangshi City before November 2011. Therefore, the synthetic result of Huangshi City is relatively stable for the result of implement of home with joint property rights.

\section{Suggestions}

According to the result of data analysis, it is known that for the city like Huangshi City, the mode of home with common property rights has a small impact on its commercial house prices. Like other similar cities in scale, location, and all kinds of resources and environment, its commercial house prices will fluctuate with the corresponding macro-control and micro-control policies issued by the state. However, the result may also be related to the fact that the mode of home with common property rights is only for low-income people, while most people don't enjoy the benefits of the mode. Thus, the proportion of housing with joint property rights is very low. Accordingly, the impact of the mode on the commercial house prices is very weak. But if Chinese Government can follow these examples like Singapore, Sweden and Hongkong to apply the mode of home with joint property rights to the lower-and middleincome groups, and adopt a series of the combination of policies, the mode may have a certain impact on the housing prices of the related city. The detailed suggestions are listed as follows:

1) Adjusting and improving the responsibilities of the existing housing management organization. At present, the Housing Reform and Development Department (Research Office) of the Ministry of Housing and UrbanRural Development of the People Republic of China is responsible for the formulation of housing policies and the guidance of the corresponding reforms, and organize the preparation and implementation of the national housing construction plans and annual plans ${ }^{[18]}$. The Department of Housing Security is responsible for the formulation, guidance and implementation of the housing security policy, and undertakes the tasks related to the arrangement for Administration of Central Government subsidies for special funds for low-rent housing guarantees, and organizes the preparation, supervision and implementation of the housing security development plan and the year-end plan ${ }^{[18]}$. However, construction and management of home with joint property rights involves many aspects, including the schedule for the proportion of financial funds in housing construction, the design for the proportion of stateowned property rights in home with joint property rights, and management of the fund for withdrawal or sales of assets. Therefore, it is vital for the construction and the corresponding fund management for home with joint property rights to combine the responsibilities and functions of the relevant departments of the Ministry of Finance with that of the Ministry of Housing and UrbanRural Development. Therefore, a special housing management organization is needed to carry out the corresponding design, construction and management.
2) Expanding the scope of the applicants for home with joint property rights. On the premise of not canceling the household registration system, it is necessary to increase the application for the housing with common property rights to low and middle income households among the local household registration population to meet the basic survival needs of the people. That is to say, for those legal residents who are below the middle-income level, the related department should consider their credit score and formulate the corresponding housing application policy for home with common property rights. At the same time, for the residents who have made outstanding contributions to society, it is quite indispensable for them to give the priority for obtaining this kind of house with joint property rights to guide the public to be inclined to goodness and praise the noble character so as to set up a good benchmark for next generations.

3) Standardizing and reconstructing the present management system, laws and regulations. For those who apply for home with joint property rights by fraud or devious means, the related government department should set up the corresponding system of rewards and punishments. In addition, they should establish a set of management system of home with joint property rights to protect the rights and interests of the owners living in this kinds of housing and clarify their obligations, it is because home with joint property rights involves divisions of housing with common property rights and subsequent problems of selling the housing such as the conditions of sale, the division of profit or loss among the stakeholders after the housing with joint property rights is sold. However, as mentioned by Jacobus and Sherriff (2009), the mode of house with common property rights is a kind of mode of safe, sustainable and affordable housing that can solve the gap between the poor and the wealth ${ }^{[19]}$. The taker of home with joint property rights enjoys the corresponding social welfare. Therefore, when the taker has purchased other estate, the housing with common property rights should be strictly forbidden to rent for the benefits and be recovered according to the agreed price.

4) Building up and perfecting the management system related to the construction of home with joint property rights. China is a socialist country. Therefore, Chinese Administration at all levels is to serve the people. Consequently, they should build up management system, the provisions of laws and regulations related to home with joint property rights for those companies that are willing to participate in construction and management of the housing with common property rights in various ways to ensure the rights and interests of the buyers who share the housing property with the company, and clarify their responsibilities, rights and other obligations in the process of market-oriented operation of home with joint property rights.

\section{Conclusion}

It is found that for Huangshi city, the mode of home with property rights has little effect on its commercial house 
prices by means of the synthetic control with the data like the commercial house prices, per capita GDP, rent, medical care, and education of Huangshi City and other selected 20 cities. The result may be related to the scope of people who are eligible to apply for the mode of home with common property rights because the proportion of the population with home with joint property rights is relatively lower in commercial house. Therefore, it puts forward the countermeasure and suggestion about construction of the laws and regulations, management system related to the stakeholders of home with joint property rights to serve the people. Among them, the stakeholders include administration, tenant, real estate developers, the company with the common property right housing, managers for home with property rights and other relevant departments.

\section{Acknowledgment}

This work is supported by The Project of Philosophy and Social Science Research in Colleges and Universities in Jiangsu Province in 2017(Grand No. 2017SJB0888). It is sponsored by Qing Lan Project in Jiangsu Province in 2017.

\section{References}

1. The experience about the shantytown renovation and the mode of home with common property rights in Huangshi City is worthy of reference [EB/OL]. http://www.zzjsxxw.gov.cn/penggai/news_view.asp ?id=17856. 2010-04-27.

2. The indemnificatory housing in Huangshi City, Hubei Province are uniformly reallocated by the government [EB/OL]. http://business.sohu.com/20101115/n277624415.sht ml. 2010-11-15.

3. Homes and Communities Agency, Council of Mortgage Lenders, National Housing Federation. Shared ownership: Joint guidance for England, June 2011.

4. S. Graham, B. Sky. "The Role of Shared Ownership in the Future Housing Market-A Discussion Paper." Blue Sky, the National Housing Federation and a group of housing associations, 2010.

5. M. Stephens. "Social Housing in the United Kingdom." The Future of Public Housing. Springer, Berlin, Heidelberg, 2013, pp. 199-213.

6. Center for Housing Policy (Washington, DC), and J. Lubell. Increasing the availability of affordable homes: A handbook of high-impact state and local solutions. Homes for Working Families, 2006.
7. Sherriff, Ryan. "Shared equity homeownership state policy review." Journal of Affordable Housing \& Community Development Law, 2010, pp. 279-311.

8. J. Lubell. "Filling the void between homeownership and rental housing: a case for expanding the use of shared equity homeownership." Homeownership Built to Last, 2014.

9. B G. Park. "Where do tigers sleep at night? The state's role in housing policy in South Korea and Singapore." Economic Geography, Vol. 74, pp. 272288, 1998.

10. J. Sørvoll, , and B. Bengtsson. "Mechanisms of solidarity in collaborative housing-The case of cooperative housing in Denmark 1980-2017." Housing, Theory and Society, Vol. 37. pp. 65-81, 2020.

11. S. L. Ng, et al. "Living environment and quality of life in Hong Kong." Asian Geographer, Vol. 35, pp. 35-51, 2018

12. I. Balmer, and J D. Gerber. "Why are housing cooperatives successful? Insights from Swiss affordable housing policy." Housing studies, Vol. 33, pp.61-385, 2018.

13. L. Vidal. "Cooperative Islands in Capitalist Waters: Limited - equity Housing Cooperatives, Urban Renewal and Gentrification." International Journal of Urban and Regional Research, Vol. 43, pp.157178,2019

14. L. Crabtree, et al. "Articulating value in cooperative housing: International and methodological review." 2019.

15. A. Abadie and J. Gardeazabal. "The economic costs of conflict: A case study of the Basque Country." American economic review, Vol. 93, pp. 113132, .(2003.

16. A. Abadie, A. Diamond, and J. Hainmueller. "Synthetic control methods for comparative case studies: Estimating the effect of California's tobacco control program." Journal of the American statistical Association, Vol. 105, pp.493-505, 2010

17. A. Abadie, A. Diamond, and J. Hainmueller. "Comparative politics and the synthetic control method." American Journal of Political Science, Vol. 59, pp. 495-510, 2015.

18. The internal department [EB/OL]. http://www.mohurd.gov.cn/gyjsb/jgjg/index.html.

19. R. Jacobus and R. Sherriff. "Balancing Durable Affordability and Wealth Creation: Responding to Concerns about Shared Equity Homeownership." Washington, DC: Center for Housing Policy, 2009.. 